Check for updates

Cite this: RSC Adv., 2017, 7, 38273

\title{
Biotechnological production of the mussel byssus derived collagen preColD $\uparrow$
}

\author{
Adrian V. Golser ${ }^{\mathrm{a}}$ and Thomas Scheibel (D) *ab

\begin{abstract}
Marine mussels adhere to substrates within the intertidal zone by means of a bundle of threads called the mussel byssus which contains several collagen-like proteins responsible for the mechanical properties of the fibers. Here, we demonstrate the biotechnological production of one of three identified byssus collagens, preColD, from Mytilus galloprovincialis using Pichia pastoris as the expression host. Previously detected structural features of natural preColD, such as collagen triple helix formation, could also be
\end{abstract} \\ detected in the recombinant preColD, even in the absence of hydroxylation of proline or tyrosine residues.
}

Received 21st April 2017

Accepted 25th July 2017

DOI: $10.1039 / \mathrm{c} 7 \mathrm{ra0} 4515 \mathrm{~h}$

rsc.li/rsc-advances

\section{Introduction}

Several marine species produce a variety of distinct materials for underwater attachment with mechanical properties ranging from those of cement ${ }^{1}$ to silk ${ }^{2}$ to softer and more elastic materials. ${ }^{3}$ These holdfasts have the ability to dissipate mechanical stress without losing their structural integrity. One of these remarkable devices is the byssus of Mytilidae, ${ }^{4}$ e.g. Mytilus galloprovincialis, which consists of several distinct threads each comprising a mechanical gradient along the fiber axis. ${ }^{5}$ This gradient of the material's Young's modulus allows the soft muscle (the mussel foot) to seamlessly connect to hard substrates without causing radial stress within the material. ${ }^{6}$

The byssus contains a variety of different proteins, including collagen-like preCols, ${ }^{7}$ which assemble into fibrils being the byssus' main load-bearing structure located in the fiber core. ${ }^{8}$ preCols (Fig. 1), are a class of structural proteins comprising a collagen core domain flanked by specific domains which strongly contribute to the overall mechanical properties of the byssus threads: ${ }^{9}$ the elastic, proximal portion of a thread is rich in preColP $^{10}$ comprising elastin-like flanking domains, whilst the tougher, more rigid portion of the thread consists mostly of preColD ${ }^{11}$ which incorporates crystalline silk-like flanking domains.

The influence of the preCol-composition on the thread's mechanics is significant: even though the preCols are embedded in a complex array of matrix proteins, ${ }^{12-14}$ the mechanical properties of the byssus thread have been largely

${ }^{a}$ Lehrstuhl Biomaterialien, Fakultät für Ingenieurwissenschaften, Universität Bayreuth, Universitätsstraße 30, 95440 Bayreuth, Germany

${ }^{b}$ Bayreuther Zentrum für Kolloide und Grenzflächen (BZKG), Bayerisches Polymerinstitut (BPI), Bayreuther Zentrum für Molekulare Biowissenschaften (BZMB), Bayreuther Materialzentrum (BayMAT), Universität Bayreuth, Universitätsstraße 30, 95440 Bayreuth, Germany. E-mail: thomas.scheibel@ uni-bayreuth.de

$\dagger$ Electronic supplementary information (ESI) available. See DOI: $10.1039 / \mathrm{c} 7 \mathrm{ra} 04515 \mathrm{~h}$ reproduced by spinning a fiber from matrix-free preCols extracted from the mussel foot. ${ }^{15,16}$

In addition to mechanical stability, all known preCols mediate various intermolecular interactions with other preCols, matrix proteins and substrates. The amino- and carboxyterminal domains of the natural preCols contain DOPA moieties for adhesion, metal binding and crosslinking, as well as histidinebased metal chelate complexes, which are likely responsible for previously detected self-healing properties of byssus threads, ${ }^{15,17}$ since the latter are fully reversible. Like other collagens, proline residues within the natural preCols are often hydroxylated at the $Y$-position in the collagen triplet (GXY) by a mussel specific hydroxylase; it is known, however, that most types of collagen will readily form triple-helices even when the content of hydroxyproline is low, albeit at lower melting points.

In this context, the lack of DOPA-residues will also reduce the crosslinking, but it is not expected to influence the protein's folding. Therefore, recombinant production of preColD was chosen as one possible strategy to investigate individual mussel byssus collagens and their properties in greater detail.

\section{Experimental section}

\section{Molecular cloning and microbiology}

The general methodology for the handling of P. pastoris, as well as the molecular biology methods utilized for obtaining the preColD expression plasmid are described in the pPICZ user manual ${ }^{18}$ and other relevant literature. ${ }^{19}$

M. galloprovincialis preColD. The gene encoding preColD was amplified from a mussel foot cDNA-Library by PCR. ${ }^{20}$ It was subsequently cloned (GenBank JQ837491) into the vector PPICZ $\alpha$ (Invitrogen, Carlsbad USA), utilizing the plasmid-intrinsic $\alpha$ secretion factor and the carboxyterminal cMyc- and His6-tags. The amplified PCR fragment was digested with XhoI and XbaI restriction enzymes (the cleavage sites were artificially inserted into the PCR primer), creating a fragment which allowed 




B



Fig. 1 (A) Schematic representation of a preColD triple helix. The central collagen sequence is based on the collagen-typical (GXY) ${ }_{n}$-repeat which is interrupted by glycine deletions. The flanking regions of preColD contain poly-alanine stretches similar to those of silks and putatively form nanocrystalline beta sheets upon higher order assembly of the thread. The chelating termini of preCols contain both histidine and DOPA residues and thereby can promote a reversible, metal dependent end-to-end arrangement between fibrils that become increasingly chemically crosslinked during the maturation of the thread. ${ }^{9}$ (B) Block schematic of the domain structure of monomeric, recombinant preColD (domain size drawn to scale).

seamless in-frame ligation into a XhoI/XbaI-digested pPICZ $\alpha$ vector using T4 ligase. The ligated DNA was transformed into $E$. coli which were plated onto LB-agar containing Zeocin $(50 \mu \mathrm{g}$ $\mathrm{mL}^{-1}$ ) and grown overnight. Resulting colonies were grown in a 4 $\mathrm{mL}$ liquid culture, plasmids were isolated using a Wizard (TM) SV Miniprep kit (Promega; Madison WI, USA) and the correct gene insertion confirmed using gene sequencing.

Transformation of P. pastoris. P. pastoris strain X33 (Invitrogen, Carlsbad USA) was transformed with $10 \mu \mathrm{g}$ of linearized pPICZ $\alpha$-preColD plasmid via electroporation. ${ }^{21,22}$ The transformants were selected for Zeocin-resistance $\left(100 \mu \mathrm{g} \mathrm{mL} \mathrm{m}^{-1}\right)$ on YPD-plates and screened (8 colonies) for maximal anti-cMycantibody binding by western blotting. The transformant showing the strongest signal in both secreted as well as intracellular recombinant protein was chosen as production strain (see ESI Fig. S1†).

\section{Fermentation of Pichia pastoris}

Fermentation was carried out in a Minifors fermenter (Infors, Basel Switzerland) according to established protocols ${ }^{23,24}$ with slight modifications. Cells were grown at $30{ }^{\circ} \mathrm{C}$ in BMGY medium (13.4 $\mathrm{g} \mathrm{L}^{-1} \mathrm{YNB}, 1 \%(\mathrm{v} / \mathrm{v})$ glycerol, $1 \%(\mathrm{w} / \mathrm{v})$ yeast extract, $2 \%(\mathrm{w} / \mathrm{v})$ peptone, $100 \mathrm{mM}$ potassium phosphate, $\mathrm{pH}$ 6.0) until the initial carbon sources were depleted and subsequently fed with $86 \%$ glycerol, $1.2 \%$ PTM1 trace salts ${ }^{25}$ at $10 \mathrm{~mL} \mathrm{~h}^{-1} \mathrm{~L}^{-1}$ starting volume until the wet cell mass reached $200 \mathrm{~g} \mathrm{~L}^{-1}$. Production of recombinant protein was induced with methanol (final concentration of $0.5 \%(\mathrm{v} / \mathrm{v})$ ). The concentration was kept stable with an automated feeding procedure controlled by a methanol sensor. The $\mathrm{pH}$ was held constant at 6.0 , and $\mathrm{pO}_{2}$ was kept at $40 \%$.

\section{Purification of recombinant preColD}

Cells were harvested by centrifugation $(6000 \mathrm{xG})$ and washed once with phosphate buffered saline (PBS; $137 \mathrm{mM} \mathrm{NaCl}$, $2.7 \mathrm{mM} \mathrm{KCl}, 10 \mathrm{mM} \mathrm{Na}_{2} \mathrm{HPO}_{4}, 1.8 \mathrm{mM} \mathrm{KH}_{2} \mathrm{PO}_{4}, \mathrm{pH}$ 7.4). The pellet was resuspended in an equal volume of buffer $\mathrm{A}(4 \mathrm{M}$ guanidinium hydrochloride in PBS) and disrupted by 5 passes through a Microfluidics M-110S homogenizer at 80 psi inlet pressure. After centrifugation $(40000 \mathrm{xG})$, the supernatant of the extract was loaded onto a high-performance Ni-NTA IMAC column (approx. $200 \mathrm{~mL}$ bed volume), washed extensively with $8 \mathrm{M}$ urea in PBS and eluted with $200 \mathrm{~mL}$ buffer A $+500 \mathrm{mM}$ imidazole. The eluate was dialyzed against $10 \mathrm{mM}$ ammonium bicarbonate and subsequently dried via lyophilization (see ESI Fig. S2 $\uparrow$ for SDS-PAGE).

\section{Transmission electron microscopy}

$200 \mu \mathrm{L}$ of preColD were desalted using a $5 \mathrm{~mL}$ HiTrap desalting column equilibrated with $50 \mathrm{mM}$ sodium acetate, $\mathrm{pH} 5.5$ and concentrated to approx. $25 \mathrm{mg} \mathrm{mL}{ }^{-1}$ using a centricon centrifugation tube with a MW cutoff of $30 \mathrm{kDa}$.

$5 \mu \mathrm{L}$ of $50 \mathrm{mM}$ TRIS/HCl pH 8.0 were applied to TEM-grids, then adding 5,1 or $0.1 \mu \mathrm{L}$ of preColD solution, respectively. After incubating for $1 \mathrm{~min}$, the grids were washed twice with $10 \mu \mathrm{L}$ TRIS-buffer and negatively stained with uranyl acetate. The samples were visualized using a Zeiss CEM 902 microscope at $80 \mathrm{kV}$.

\section{CD and FTIR spectroscopy}

CD spectra were recorded with a Jasco J-815 spectrometer at $20{ }^{\circ} \mathrm{C}$ (scanning speed: $50 \mathrm{~nm} \mathrm{~min}^{-1}$; band width: $1.7 \mathrm{~nm}$; D.I.T.: 2 s; accumulations: 5). Films were poured onto glass slides from a $5 \mathrm{mg} \mathrm{mL}^{-1}$ solution in formic acid and measured directly after the evaporation of the solvent. preColD in solution was measured in a $1 \mathrm{~mm}$ quartz cuvette after dialyzing the same solution against PBS and PBS containing $4 \mathrm{M}$ urea at $4{ }^{\circ} \mathrm{C}$. FTIR spectra were recorded with a Bruker Tensor 27 spectrometer, using a PIKE Miracle Ga-ATR crystal. The films were prepared directly on the freshly cleaned crystal by allowing the solvent to evaporate from $10 \mathrm{mg} \mathrm{mL} \mathrm{m}^{-1}$ solutions of protein (preColD, gelatin, spider silk protein eADF4(C16)) in formic acid. The spider silk protein, after measuring the freshly prepared film, was additionally treated with methanol to induce beta-sheet formation. The obtained spectra were smoothed, baselineadjusted and corrected for atmospheric moisture. 
(A)

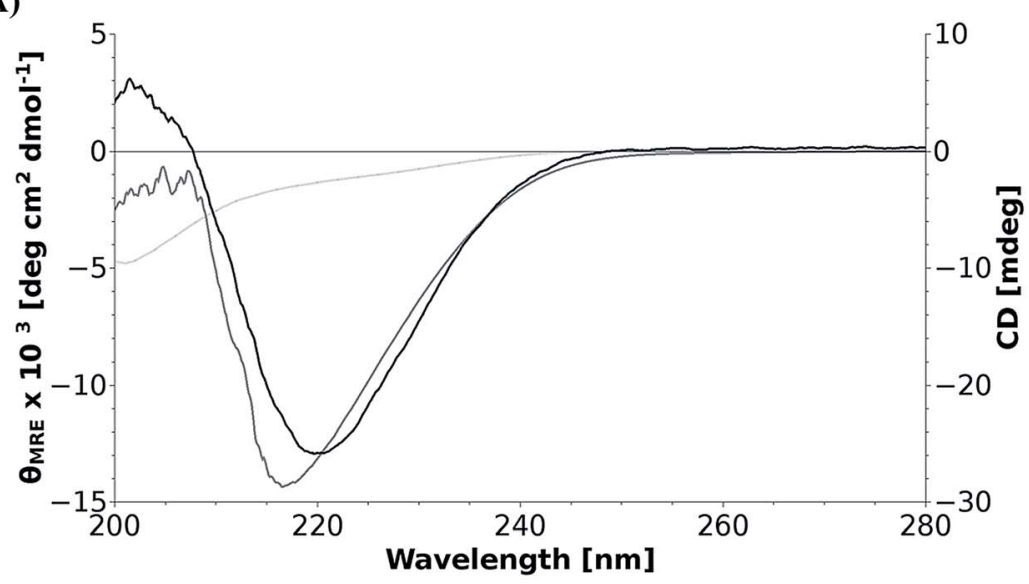

(B)
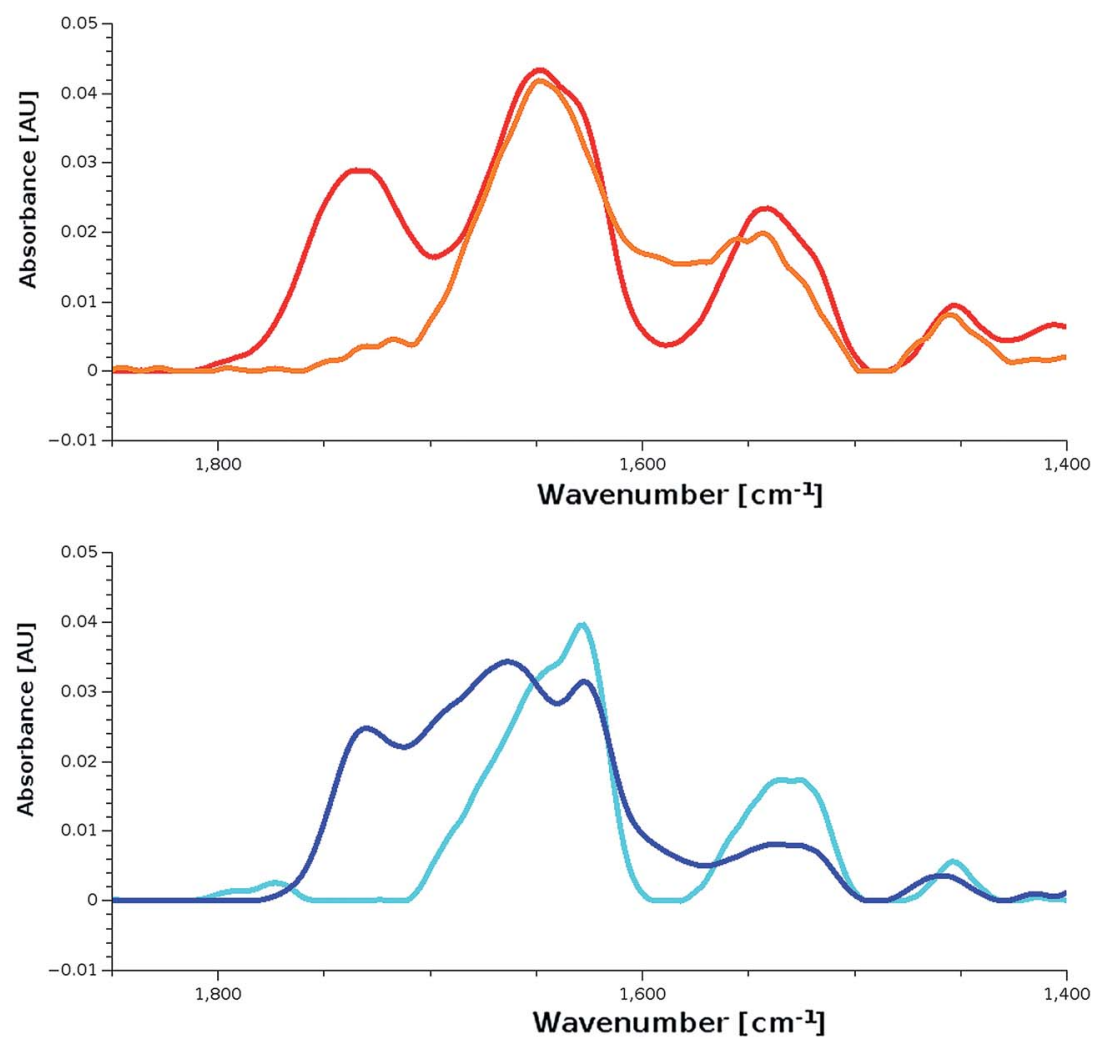

Fig. 2 (A) CD spectra of preColD film (black) and solutions ( $5 \mathrm{mg} \mathrm{mL}^{-1}$ ) in PBS containing no urea (light gray) and $4 \mathrm{M}$ urea (dark gray). The film sample shows a $2 \mathrm{~nm}$ redshift possibly due to the lack of solvent. All samples show minima/shoulders at 218-220 nm which correspond to $\beta$-sheets most likely forming within the silk-like flanking domains of preColD. The spectrum of the non-denatured sample seems to consist of an overlay of the aforementioned $\beta$-sheets and triplehelical collagen which typically shows a small positive peak at 220-225 nm and a larger negative peak at $200 \mathrm{~nm}$. (B) FTIR-spectra of protein films. Gelatin (orange), random coil spider silk protein (red), preColD (dark blue), $\beta$-sheetrich spider silk protein (cyan). Unstructured or helical proteins have an amide I peak at around $1650 \mathrm{~cm}^{-1}$, as seen for gelatin and unstructured spider silk protein, while $\beta$-sheets have a peak at around $1635 \mathrm{~cm}^{-1}$ (crystalline spider silk protein). preColD shows two peaks in the amide I region, of which one corresponds to $\beta$-sheets and the other one corresponds to unstructured elements.

\section{Results and discussion}

\section{Production and purification of preColD}

P. pastoris can be a suitable host for the production of secreted proteins, which simplifies downstream processing steps during recombinant protein production. Therefore, preColD was cloned with an $\alpha$-secretion factor inducing translocation into the endoplasmic reticulum (ER) and subsequent secretion via the Golgi apparatus. Accordingly, the selection for the highest producing $P$. pastoris expression strain was performed by 


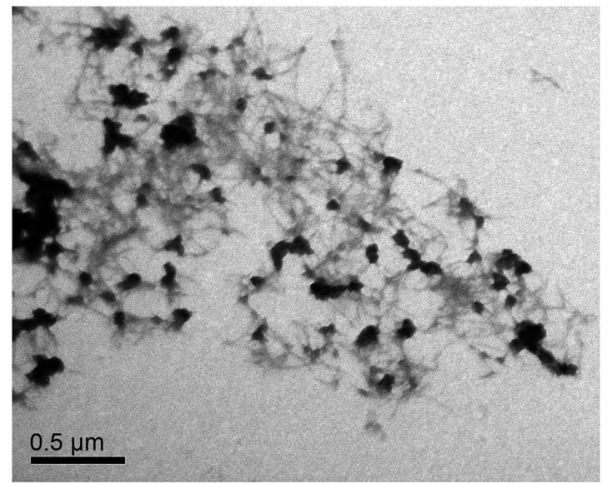

Fig. 3 TEM analysis of recombinant preCoID shows fibrils with lengths of $180 \mathrm{~nm}$ and assemblies thereof. The single fibrils interact at the termini, sometimes forming globular aggregates and dense fibril bundles.

screening for both intracellular as well as secreted transgenic cMyc-Antigen that is present at the carboxyterminus of recombinant preColD (Fig. 1B). The screening was performed in shake flask culture, and secreted protein levels corresponded well with intracellular retention (see ESI Fig. S1 †).

Nevertheless, apparently no secretion past the yeast cell wall took place during fermentation, since no recombinant protein could be detected in the medium. Therefore, the recombinant protein was purified from the cell pellet. A single band at the expected molecular weight could be detected by SDS-PAGE (ESI Fig. S2 $\uparrow$ ), suggesting that the recombinant preColD was successfully translocated into the endoplasmic reticulum (ER), had its secretion factor cleaved as expected, but could not be secreted due to unknown reasons. The most likely explanation therefore is a difference in relative expression levels due to the scale-up, since the induction level is dependent on the methanol concentration, which is kept constant during fermentation but isn't monitored in shake flasks.

The yield of pure recombinant preColD from a $1 \mathrm{~L}$ fermentation up to $350 \mathrm{~g} \mathrm{~L}^{-1}$ wet cell mass was $252 \mathrm{mg}$ when purified according to the protocol in the experimental section. While this is low compared to industrial processes employing P. pastoris, ${ }^{26}$ this number is adequate for lab scale production using a non-optimized system.

\section{Determination of secondary structures}

The $\beta$-sheet signal observed in the CD spectra (Fig. 2A) suggest a strong influence of the silk-like flanking domains on the overall structure of preColD, as they are present even under denaturing conditions ( $4 \mathrm{M}$ urea) and when dried from formic acid, conditions that would usually favor random coil structures.

Under physiological conditions, the signal intensity was reduced, suggesting that the negative $\beta$-sheet-peak $(218 \mathrm{~nm})$ is partially canceled out by the positive peak from triple-helical collagen $(220 \mathrm{~nm})$. The emergence of a negative peak around $200 \mathrm{~nm}$, which is also expected for folded collagen, supports this hypothesis. It is known that denatured collagen mostly loses its CD-active properties (loss of positive peak at $220 \mathrm{~nm}$, reduction of mean residual ellipticity at $200 \mathrm{~nm}$ from -30 to $-5 \times 10^{3} \mathrm{deg} \mathrm{cm}^{2} \mathrm{dmol}^{-1}$ ), while non-collagenous proteins would instead show a random-coil structure, which would interfere with the $\beta$-sheet-signal also under denaturing conditions. ${ }^{27,28}$ The spectra of preColD in solution at $4 \mathrm{M}$ and $0 \mathrm{M}$ urea have been compared to reference spectra using the web-based tool $\mathrm{K} 2 \mathrm{D} 3{ }^{29}$ showing no similarity to standard proteins present in the database, which supports the hypothesis of having mixed signals (ESI Fig. S3†).

Additional experiments suggesting the presence of $\beta$-sheets as well as unstructured collagen have been obtained for films of preColD via FTIR (Fig. 2B). The recombinant spider silk protein eADF4(C16) was used as a control to visualize the peak shift towards lower wavenumbers that occurs when beta sheet formation is induced in the previously unstructured film ${ }^{30,31}$ which, in this measurement, manifests itself as a shift of the amide I peak from $1645 \mathrm{~cm}^{-1}$ to $1630 \mathrm{~cm}^{-1}$. Commercial gelatin was used as a control to determine the signal obtained by an unstructured collagen-like protein, and corresponds to that of a random coil protein at $1645 \mathrm{~cm}^{-1}$. preColD has two peaks within the amide I band, one suggesting the presence of betasheets $\left(1645 \mathrm{~cm}^{-1}\right)$, the other suggesting the presence of random coil structures or helices $\left(1660 \mathrm{~cm}^{-1}\right)$.

While no Fourier self deconvolution was performed, it is evident that a part of preColD contains structural features that can be compared to those of silk proteins under the given conditions, while another portion of the protein seems to contain structures that correspond to unstructured or alphahelical proteins, similar to those obtained by unstructured gelatin.

We hypothesize that the silk-like flanking domains of preColD form a stable, $\beta$-sheet-rich structure under virtually all conditions, being largely responsible for the stiffness of the distal portion of the natural mussel byssus. The collagen core appears to be stable at room temperature even when not hydroxylated, but loses its folding under denaturing conditions. Additionally, the formation of the collagen triple-helix seems to be kinetically hindered, ${ }^{32}$ since it does not appear when the denaturing solvent is removed quickly, such as during the preparation of films.

\section{Fibrillization of preColD}

Natural preCols extracted from the foot of M. edulis undergo fibrillization when the $\mathrm{pH}$ is increased above the $\mathrm{pK}_{\mathrm{a}}$ of histidine, as this enables the chelation of metal ions by the HIS/ DOPA-rich termini of the proteins which thereby promote intermolecular interactions. ${ }^{17,33}$ Here, we analyzed the assembly of recombinant preColD under similar conditions. Preliminary experiments haven shown that the dilution of a highly concentrated solution of preColD in formic acid rapidly results in unspecific aggregation (ESI Fig. S4 $\dagger$ ), while dilute solutions of preColD undergo fibrillization within the same timescale after shifting the $\mathrm{pH}$ from 5.5 to 8.0 (Fig. 3). This has also been described for the natural extract of mixed preCols in ref. 33. Our recombinant fibrils also show similar properties as the natural 
extract in regard to size and intermolecular arrangement and, as expected, lack any amyloid-like features such as Thioflavin T binding. The presence of globular structures, as seen here, has not been described for the natural extract and seems to be depending on the preparation of the samples. However, since these structures are only observable in the vicinity of high densities of fibrils, they likely result from higher order assembly and/or aggregation of preColD trimers, which might likely be the result of artifacts due to the sample preparation.

\section{Conclusions}

The mussel byssus collagen preColD of $M$. galloprovincialis could be recombinantly produced in $P$. pastoris and successfully purified under denaturing conditions using IMAC. It was shown that, even when no posttranslational modifications are present, preColD still has the ability to form nanofibrils under native conditions, which appeared to be similar to those obtained when subjecing natural preCols extracted from mussel feet to the same conditions. ${ }^{33}$

The secondary structure of soluble preColD and films made thereof showed $\beta$-sheet structures even under mild denaturing conditions, which suggests that the silk-like flanking domains are involved in early-on structure formation of preColD. Further, they might play a central role in providing physical stability and chemical resilience in the natural byssus thread, since they have been shown in silk to withstand even stronger denaturing conditions. ${ }^{34-36}$ Furthermore, the data obtained by CD and FTIR spectroscopy suggest the presence of correctly folded collagen triplehelices. Since the formation of collagen triplehelices is kinetically hindered due to the very slow proline cis/trans isomerization, it is believed that the unique structure of the flanking regions ${ }^{15,37,38}$ is involved in premature assembly similar to the function of pro-domains in vertebrate collagens ${ }^{39}$ and certain foldons in bacterial collagens. ${ }^{\mathbf{4 0 , 4 1}}$ This stabilizing effect seems to be sufficient to compensate for the decrease in stability due to the absence of hydroxyprolines.

Conclusively, the deeper understanding of byssus collagens can serve as an inspiration for the development of biotechnologically produced, protein-based, highly resilient biopolymers with adjustable functions.

\section{Acknowledgements}

The authors thank Dr A. Hagenau for providing the mussel foot cDNA library as well as K. Schacht (Biomaterials, University of Bayreuth), R. Grotjahn and PD Dr S. Geimer (Electron Microscopy, University of Bayreuth) for assistance with TEM. Fig. 1B was created using DomainDraw. ${ }^{42}$ This work was funded by DFG Grant SCHE603/14-1. A. Golser (MSc) received a scholarship from the Bayerisches Eliteförderungsgesetz (BayEFG).

\section{References}

1 R. R. Despain, K. L. De Vries, R. D. Luntz and M. L. Williams, J. Dent. Res., 1973, 52, 674-679.
2 K. Kronenberger, C. Dicko and F. Vollrath, Naturwissenschaften, 2012, 99, 3-10.

3 M. E. Callow and J. E. Callow, Biologist, 2002, 49, 10-14.

4 J. P. Pujol, Nature, 1967, 214, 204-205.

5 J. E. Smeathers and J. F. V. Vincent, J. Mollus. Stud., 1979, 45, 219-230.

6 J. H. Waite, E. Vaccaro, C. Sun and J. M. Lucas, Philos. Trans. R. Soc. London, Ser. B, 2002, 357, 143-153.

7 A. Hagenau, M. H. Suhre and T. Scheibel, Prog. Polym. Sci., 2014, 39, 1564-1583.

8 X. Qin and J. H. Waite, J. Exp. Biol., 1995, 198, 633-644.

9 J. H. Waite, X. X. Qin and K. J. Coyne, Matrix Biol., 1998, 17, 93-106.

10 K. J. Coyne, X. X. Qin and J. H. Waite, Science, 1997, 277, 1830-1832.

11 X. X. Qin, K. J. Coyne and J. H. Waite, J. Biol. Chem., 1997, 272, 32623-32627.

12 M. H. Suhre and T. Scheibel, J. Struct. Biol., 2014, 186, 75-85. 13 M. H. Suhre, M. Gertz, C. Steegborn and T. Scheibel, Nat. Commun., 2014, 5, 3392.

14 M. H. Suhre, T. Scheibel, C. Steegborn and M. Gertz, Acta Crystallogr., Sect. F: Struct. Biol. Commun., 2014, 70, 769-772.

15 A. Hagenau, P. Papadopoulos, F. Kremer and T. Scheibel, J. Struct. Biol., 2011, 175, 339-347.

16 T. Priemel, E. Degtyar, M. N. Dean and M. J. Harrington, Nat. Commun., 2017, 8, 14539.

17 M. J. Harrington, H. S. Gupta, P. Fratzl and J. H. Waite, J. Struct. Biol., 2009, 167, 47-54.

18 ppiczalpha_man.pdf, https:/tools.thermofisher.com/ content/sfs/manuals/ppiczalpha_man.pdf, accessed June 28, 2017.

19 D. R. Higgins and J. Cregg, Pichia Protocols, Humana Press, 2008.

20 J. M. Lucas, E. Vaccaro and J. H. Waite, J. Exp. Biol., 2002, 205, 1807-1817.

21 C. A. Scorer, J. J. Clare, W. R. McCombie, M. A. Romanos and K. Sreekrishna, Biotechnology, 1994, 12, 181-184.

22 J. M. Cregg and K. A. Russell, Methods Mol. Biol., 1998, 103, 27-39.

23 K. Sreekrishna, R. H. Potenz, J. A. Cruze, W. R. McCombie, K. A. Parker, L. Nelles, P. K. Mazzaferro, K. A. Holden, R. G. Harrison and P. J. Wood, J. Basic Microbiol., 1988, 28, 265-278.

24 G. P. L. Cereghino, J. L. Cereghino, C. Ilgen and J. M. Cregg, Curr. Opin. Biotechnol., 2002, 13, 329-332.

25 J. Stratton, V. Chiruvolu and M. Meagher, Methods Mol. Biol., 1998, 103, 107-120.

26 B. Brodsky and J. A. M. Ramshaw, in Fibrous Proteins: Structures and Mechanisms, ed. D. A. D. Parry and J. M. Squire, Springer International Publishing, cham, 2017, vol. 82, pp. 601-629.

27 N. J. Greenfield, Nat. Protoc., 2007, 1, 2527-2535.

28 T. Hyashi, S. Curran-Patel and D. J. Prockop, Biochemistry, 1979, 18, 4182-4187.

29 C. Louis-Jeune, M. A. Andrade-Navarro and C. Perez-Iratxeta, Proteins: Struct., Funct., Bioinf., 2012, 80, 374-381. 
30 K. Spiess, A. Lammel and T. Scheibel, Macromol. Biosci., 2010, 10, 998-1007.

31 U. Slotta, S. Hess, K. Spieß, T. Stromer, L. Serpell and T. Scheibel, Macromol. Biosci., 2007, 7, 183-188.

32 S. Boudko, S. Frank, R. A. Kammerer, J. Stetefeld, T. Schulthess, R. Landwehr, A. Lustig, H. P. Bächinger and J. Engel, J. Mol. Biol., 2002, 317, 459-470.

33 M. J. Harrington and J. H. Waite, Biomacromolecules, 2008, 9, 1480-1486.

34 F. Bauer and T. Scheibel, Angew. Chem., Int. Ed. Engl., 2012, 51, 6521-6524.

35 G. Lang, H. Herold and T. Scheibel, Subcell. Biochem., 2017, 82, 527-573.
36 D. Huemmerich, T. Scheibel, F. Vollrath, S. Cohen, U. Gat and S. Ittah, Curr. Biol., 2004, 14, 2070-2074.

37 A. Hagenau and T. Scheibel, J. Adhes., 2010, 86, 10-24.

38 A. Hagenau, H. A. Scheidt, L. Serpell, D. Huster and T. Scheibel, Macromol. Biosci., 2009, 9, 162-168.

39 J. P. Malone, K. Alvares and A. Veis, Biochemistry, 2005, 44, 15269-15279.

40 Y. Xu, D. R. Keene, J. M. Bujnicki, M. Höök and S. Lukomski, J. Biol. Chem., 2002, 277, 27312-27318.

41 Z. Yu, O. Mirochnitchenko, C. Xu, A. Yoshizumi, B. Brodsky and M. Inouye, Protein Sci., 2010, 19, 775-785.

42 J. L. Fink and N. Hamilton, In Silico Biol., 2007, 7, 145-150. 